\title{
Antimicrobial, antidiarrhoeal and analysis of phytochemical constituents of Sphaeranthus amaranthoides \\ ${ }^{*} \mathrm{~L}$. Swarna Latha and P. Neelakanta Reddy** \\ ${ }^{*}$ Department of Biotechnology, Sathyabama University, Chennai 600 119, India. \\ ** Department of Bioorganic Chemical Laboratory, Central Leather Research Institute, Chennai 600020. \\ loki_swarna@yahoo.com; drylcphd@gmail.com
}

Abstract: The ethnomedicinal value of Spheranthus amaranthoides was investigated through phytochemical study, in vitro antibacterial- and antidiarrhoeal- activity of ethanolic extracts. The analysis of the extracts revealed the presence of flavonoids, carbohydrate, tannins, saponins, steroids, glycosides, terpenoids and alkaloids. The extract evinced antibacterial activity on all the tested organisms viz. Staphylococcus aureus, Pseudomonas aeruginosa, Proteus mirabilis, Enterococcus faecalis and Escherichia coli at the concentration ranged from 50$400 \mu \mathrm{g} / \mathrm{ml}$ as assayed by disc diffusion. $S$. amaranthoides also caused a significant $(p<0.001)$ castor oil induced antidiarrhoeal effect in rats. The results suggest that these activities might be due to the presence of the potent phytochemicals in the extract of Spheranthtus amaranthoides that can be used as a therapeutic agent. Keywords: Spheranthus amaranthoides, phytochemicals, castor oil induced diarrhea.

Introduction

Consumption of medicinal herbs is tremendously increasing over a past decade as an alternative approaches to improve the quality of life and maintain a good health. Medicinal plants have been used for centuries as remedies for human diseases (Nostro et al., 2000; Arokiyaraj et al., 2008; Gangadevi et al, 2008). Extensive studies of the adverse effects of these herbal medicines and establishment of a good correlation between biomarkers and plants are essential for ensuring the efficiency and quality of herbal medicines. Recently, there has been growing interest in exploiting the biological activities of flora and fauna owing to their natural origin, cost effectiveness and lesser side effects (Rehan Ahmad et al., 2008; Chellaram \& Edward, 2009). Plant-based natural constituents can be derived from any part of the plant like bark, leaves, flowers, roots, fruits, seeds, etc (Gordon, 2001). The medicinal actions of plants unique to particular plant species or groups are consistent with the concept that the combination of secondary products in a particular plant is taxonomically distinct (Wink et al., 1999).

The acceptance of traditional medicine as an alternative form of health care and the development of microbial resistance to the available antibiotics has led researchers to investigate the antimicrobial herbal extracts (Bisignano et al., 2000; Hammer et al., 1999). Plants containing flavonoides, terpenoids, steroids, phenolic compounds and alkaloids have been reported to have antimicrobial activity (Hostettmann et al., 1977).

The WHO has continued a diarrhoeal disease control programme which includes studies of traditional medicinal practices together with the evaluation of health education and preventive approaches. This wipes out the increasing mortality rate in developing countries due to diarrheoa. Therefore, it is necessary to establish the scientific basis for the therapeutic actions of traditional plant medicines as these may serve as the source for the development of more effective drugs.

Sphaeranthus amaranthoides Linn. (SPA) is a small procumbent herb, with stems rooting and pubescent with appressed hairs, leaves palmately 3-foliolate. This plant is well known for its medicinal value for the treatment of eczema, blood disorders, stomach worms, filaria, fever and as a remover of kapha, vata and piles. It is also known to cure skin diseases (Kirtikar \& Basu, 1971). Many plants being used as an antibacterial and antidiarrhoeal agent, the effect of Sphearanthus amaranthoides Linn against diarrhoea and bacteria has not been investigated. This study was aimed the anti bacterial activity of different solvent extracts of SPA against human pathogenic bacteria and antidiarrhoeal activity of SPA on castor-oil induced diarrhoea in rats. The bacterial organisms used in this study are known for wound infection, diarrhoea, pneumonia and chest pain.

Materials and methods

Animals

Male Wistar rats $(150-200 \mathrm{~g})$ obtained from Experimental Animal Department, King's Institute, Guindy, Chennai were used in the study. The rats were fed standard laboratory diet, given water ad labium and maintained under laboratory condition of temperature $22 \pm$ $1^{\circ} \mathrm{C}$, relative humidity $14 \pm 1$ and $12 \mathrm{~h}$ light: $12 \mathrm{~h}$ dark cycle. Phytochemical screening

Conventional standard protocols (Odebiyi \& Sofowora, 1978; Trease \& Evans, 1983) for detecting the presence of different chemical constituents in the plant extract were employed. The tests for the secondary metabolites viz. alkaloids, tannins, saponins, glycosides, flavonoids and phenols were carried out.

Preparation of the crude extracts: Hundred grams of $S$. amaranthoides air-dried and coarsely powdered plant material was extracted with ethanol $(98.8 \%)$ for $2 \mathrm{~h}$. The ethanol extract was filtered and evaporated under reduced pressure using Rota-vapor. The extract was dissolved in dimethyl-sulphoxide to make the final concentrations which kept in refrigerator till used.

Preparation of the tested organisms: In vitro screening for antimicrobial study was carried out using selected disease causing pathogens which includes two gram +ve bacteria (Staphylococcus aureus and Enterococcus faecalis) and three gram -ve bacteria (Escherichia coli, Pseudomonas aeruginosa and Proteus mirabilis). Five strains each of bacterial species were used in this study. These organisms were identified by following the standard microbiological methods (Collins \& Lyne, 1995).
Research article

(CIndian Society for Education and Environment (iSee) "antidiarrhoeal herb"

http://www.indjst.org
Latha \& Reddy Indian J.Sci.Technol. 


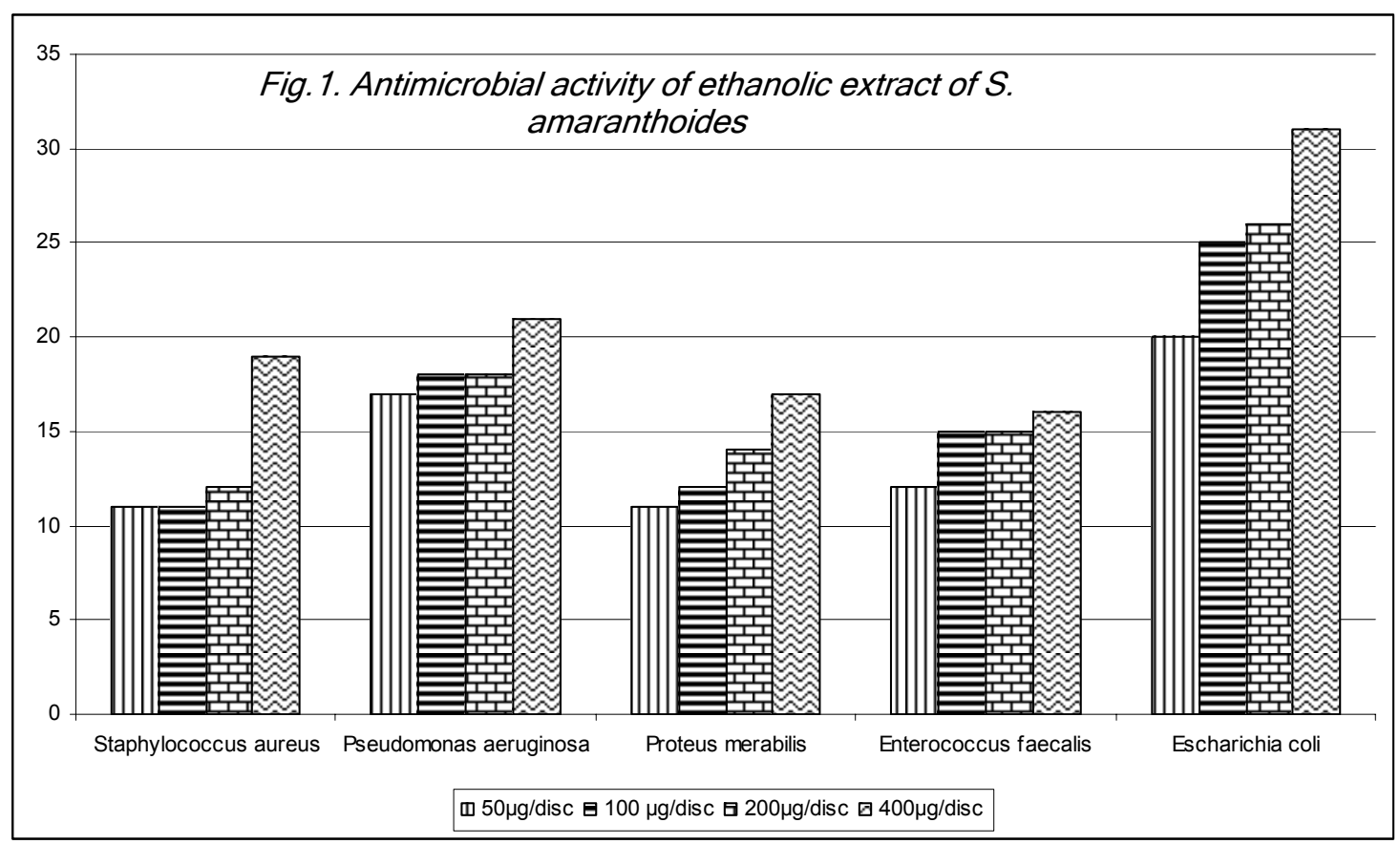

toxicity, mortality and weighed for 14 days (Tijani et al., 1986)

Anti-diarrhoeal activity

Test was performed according to (Mandal, 1997) with minor modifications. Rats of either sex were tested for $18 \mathrm{~h}$ and randomly assigned to six groups of six animals each. The doses of the extract (SPA) selected on a trial basis, were administered orally (200, and $400 \mathrm{mg} / \mathrm{kg}$ suspended in saline) to three groups of animals. The fourth

The antibacterial screening of the extracts were carried out by determining the zone of inhibition using disc diffusion method (Rath et al., 1999; Sahoo et al, 2006). The strains of microorganisms obtained were inoculated in conical flask containing $100 \mathrm{ml}$ of nutrient broth. These conical flasks were incubated at $37^{\circ}$ for $24 \mathrm{~h}$ and were referred to as seeded broth. The density of the bacterial suspension was standardized by standard McFarland method (Mc Farland et al., 1987). The extracts were dissolved in dimethyl formamide which was previously tested for antibacterial activity against all test bacteria and found to have no antibacterial activity. The extracts were made solution at a concentration of $50 \mathrm{mg} / \mathrm{ml}$ and finally sterilized by filtration using $0.45 \mu \mathrm{m}$ Millipore filters. The sterile discs (6 $\mathrm{mm}$ in diameter) were impregnated with 20 and $2.5 \mu \mathrm{l}$ of above extract solution to achieve desired concentration of 500 and $250 \mu \mathrm{g} / \mathrm{disc}$ and placed in inoculated agar. Gentamicin (G) $(10 \mu \mathrm{g} /$ disc) and Ciprofloxacin (CF) $(25 \mu \mathrm{g} / \mathrm{disc})$ were used as standards. The controls were prepared using the same solvents employed to dissolve the extracts. The inoculated plates with the test and standard discs on them were incubated at $37^{\circ} \mathrm{C}$ for $24 \mathrm{~h}$.

\section{Acute toxicity (LD50) study}

Acute toxicity study was carried out using the method of (Lorke, 1983). In the first phase, nine rats randomly divided into three groups of three rats per group were given 10,100 and $1000 \mathrm{mg}$ extract/kg body weight orally (via a cannula), respectively. The rats were observed for signs of adverse effects and death for $24 \mathrm{~h}$ and then weighed daily for 14 days. In the second phase of the study, the procedure was repeated using three rats randomly divided into three groups of one rat each, given 1600,2900 and $5000 \mathrm{mg}$ extract $/ \mathrm{kg}$ body weight, respectively. The rats were also observed for signs of group of animals received $5 \mathrm{mg} / \mathrm{kg}$ body weight of diphenoxylate orally as a standard drug. The fifth group, which served as a control received $2 \% \mathrm{v} / \mathrm{v}$ saline only. One hour after the treatment each animal received $1 \mathrm{ml}$ of castor oil orally and then observed for detection up to $4 \mathrm{~h}$ after. The presence of characteristic diarrhoeal droppings was noted in transparent plastic dishes placed beneath individual cages.

Statistical analysis

Results were expressed as the mean \pm standard error of mean (S.E.M). Statistical analysis of data was carried out using one-way analysis of variance (ANOVA) followed by Student's $t$-test. Differences in mean were considered to be significant when $p<0.001$.

Results and discussion

Phytochemical analysis

Phytochemical analysis of the ethanol extract revealed the presence of steroids, triterpenoids, phenols flavonoids, tannins and glycoside compounds. Further phytochemical analysis of ethanol extract has made SPA medicinally important (Morebise et al., 2002).

Antibacterial activity of ethanolic extract of SPA

According to World Health Report on infectious diseases 2000, overcoming antibiotic resistance is the major issue for the next millennium. As antibiotics provide the main basis for the therapy of bacterial infections the high genetic variability of bacteria enables them to rapidly evade the action of antibiotics by developing antibiotic resistance. Due to lack of information on the screening / evaluation of diverse plants for their antibacterial potential there has been a continuing search for new and more potent antibiotics (Heisig, 2001).

The antimicrobial activity (zone of inhibition) was shown in Fig.1. The ethanol extracts of SPA was
Research article

Clndian Society for Education and Environment (iSee) "antidiarrhoeal herb"

http://www.indjst.org
Latha \& Reddy Indian J.Sci.Technol. 
subjected to a preliminary screening for antimicrobial activity against Staphylococcus aureus, $P$. aeruginosa, $P$. mirabilis, E. faecalis and E. coli. Thereby SPA exhibited

evidence for our study, that the prostaglandin highest activity against all the tested strains. It showed highest activity against E.coli (31mm).

The observed activity may be due to the presence of potent

phytoconstituents in the extracts (Ikram \& Innamual 1980a, 1980b) and present investigation on the phytochemical analysis of SPA refers to the presence alkaloids, glycosides, saponins, tannins, triterpenoids, flavonoides, fixed oils and simple phenol compounds which might be responsible for its antimicrobial properties. Though the body system is made in such a way that it tackles invading foreign substances in most cases, the body system is incapable to do so and needs to be protected, enhanced and activated (Murray et al., 1990). This ability to activate the body defense mechanism or to protect the body system has been found to be present in some nature vegetation/herbal sources (Morebise et al., 2002). Table 1 shows the antibacterial activity of SPA in terms of zone of inhibition in $\mathrm{mm}$.

Antidiarrhoeal activity of ethanolic extract of SPA

Table 2 shows the effect of ethanolic extract of castor-oil induced diarrhoea in wistar rats. The ethanolic extract of SPA at doses of 200 and $400 \mathrm{mg} / \mathrm{kg}$, reduced significantly in a dose dependent way. The frequency of defecation and the wetness of fecal droppings when compared with untreated Tween80, thereby exhibited an anti-diarrhoeal activity. The dose of $400 \mathrm{mg} / \mathrm{kg}$ of SPA treated seems to show an equivalent effect of that of 5 $\mathrm{mg} / \mathrm{kg}$ of diphenoxylate.

Ricinoleic acid the active principle in castor oil caused changes in mucosal cell layer permeability, electrolyte transport and intestinal peristalsis, leading to prostaglandin secretion, which results in an increase in the secretion of water and electrolytes into the small intestine (Zavala et al., 1988). The gut wall contains prostaglandins $\mathrm{E}$ and $\mathrm{F}$ with prostaglandin synthetase activity mainly in the mucosa that cause intestinal cramps and diarrhoea which might be due to effect on intestinal smooth muscle and secrection (Galvez et al., 1993). Moreover prostaglandin contributes to the pathophysiological functions gastrointestinal tract (Sanders, 1984). Further, the studies of Ferreria et al. (1972) also revealed an

Table 2. Effect of S. amaranthoides ethanol extract on castor oil induced diarrhrea in rats

Research article

Clndian Society for Education and Environment (iSee) pharmacological properties. Woldemichael et al., 2003).

\section{References} site: http://www.indjst.org

$$
\text { control: } n=6 \text { animals in each group }
$$

"antidiarrhoeal herb"

http://www.indjst.org
Vol.2 No 3 (Mar. 2009)

ISSN: 0974- 6846 Table 1. Antibacterial activity of ethonolic extract of SPA biosynthesis inhibitors delayed castor oil induced
diarrhoea. Zone of inhibition in $\mathrm{mm}$ Concentration of SPA in $\mu \mathrm{g} / \mathrm{ml}$

\begin{tabular}{|l|l|l|}
\hline $00 \mu \mathrm{g} / \mathrm{disc}$ & $200 \mu \mathrm{g} / \mathrm{disc}$ & $400 \mu \mathrm{g} / \mathrm{disc}$ \\
\hline $1 \mathrm{~mm}$ & $12 \mathrm{~mm}$ & $19 \mathrm{~mm}$ \\
\hline $8 \mathrm{~mm}$ & $18 \mathrm{~mm}$ & $21 \mathrm{~mm}$ \\
\hline $2 \mathrm{~mm}$ & $14 \mathrm{~mm}$ & $17 \mathrm{~mm}$ \\
\hline $5 \mathrm{~mm}$ & $15 \mathrm{~mm}$ & $16 \mathrm{~mm}$ \\
\hline $5 \mathrm{~mm}$ & $26 \mathrm{~mm}$ & $31 \mathrm{~mm}$ \\
\hline
\end{tabular}

The use of native plants for the diarrhoea has become a common practice in many folk medicines. As mentioned, various species of treatment of Speranthus is used for the treatment of diarrhea. In the present investigation the rats fed with different doses of ethanolic extract of SPA effectively inhibited diarrhoea. The anti-diarrhoeal activity may thus be attributed to the presence of Tannins, the phytochemical which is known to reduce the effect through denaturing the proteins by the formation of protein tannate, thereby causing the intestinal mucosa more resistant and reduces secretion (Tripathi, 1994). Hence tannins present in the extract may be responsible for their medicinal anti-diarrhoeal activity (Yu et al., 2000; Devi et al., 2002) and also, be partly responsible for other

To conclude, the present investigation clearly reveals the antibacterial nature of this plant and suggests that this plant could be exploited in the management of diseases caused by the tested bacteria in human. Further ethanolic extract of SPA in graded doses reduced diarrhoea and thereby lending support to use SPA in folklore medicine against chronic diarrhea. The phytochemical analysis revealed that the active principle, a phenolic compound present in the ethanolic extract of SPA, is thus responsible for the antibacterial and antidiarroheal activity. It has become expedient to examine scientifically the protective effects of these herbal plants and thus there has been a continuing search for new and more potent antibiotics (Heisig, 2001). Therefore there is an increased need for research in the investigations on plants as a source of human disease management (Aiyelagabe et al., 2000; Mouniswamy et al., 2002;

1. Arokiyaraj S, Radha R, Martin S and Perinbam K (2008) Phytochemical analysis and anti-diabetic activity of Cadaba fruticosa R.Br. Indian J. Sci.Technol. 1 (6), 1-4. Domain

2. Bisignano $G$, Sanogo $R$, Marino $A$, Aquino $R$, D'Angelo V, Germanò MP, De Pasquale R and Pizza C (2000) Antimicrobial activity of Mitracarpus scaber extract and isolated constituents. Lett. Appl. Microbiol. 30, 105-108.
Latha \& Reddy Indian J.Sci.Technol. 
3. Chellaram C and Edward JKP (2009) Anti-inflammatory potential of coral reef associated gastropod, Drupa margariticola. Indian J. Sci.Technol. 2 (2), 75-77. Domain site: http://www.indjst.org.

4. Collins LV, Kristian SA, Weidenmaier C, Faigle M, Van Kessel KP, Van Strijp JA, Götz F, Neumeister B and Peschel A (2002) Staphylococcus aureus strains lacking Dalanine modifications of teichoic acids are highly susceptible to human neutrophil killing and are virulence attenuated in mice. J. Infect. Dis. 186, 214-219.

5. Court WE, Evans WC and Trease GE (1957) The structure of the root and stem of Rauwolfia caffra Sond. J. Pharm. Pharmacol. 9, 237-250.

6. Devi BP, Boominathan R and Mandal SC (2002) Evaluation of anti-diarrheal activity of Cleome viscosa L. extract in rats. Phytomedicine. 9, 739-742.

7. Ferreira SH, Herman A and Vane JR (1972) Proceedings: Prostaglandin generation maintains the smooth muscle tone of the rabbit isolated jejunum. Br. J. Pharmacol. 44, 328P-329P.

8. Galvez J, Zarzuelo A, Crespo ME, Lorente MD, Ocete MA and Jiménez J (1993) Antidiarrhoeic activity of Euphorbia hirta extract and isolation of an active flavonoid constituent. Planta Med. 59, 333-336.

9. Gangadevi V, Yogeswari S, Kamalraj S, Rani G and Muthumary J (2008) The antibacterial activity of Acalypha indica L. Indian J. Sci.Technol. 1 (6), 1-5. Domain site: http://www.indjst.org.

10. Gordon DM (2001) Geographical structure and host specificity in bacteria and the implications for tracing the source of coliform contamination. Microbiology. 147, 10791085.

11. Hammer KA, Carson CF and Riley TV (1999) Antimicrobial activity of essential oils and other plant extracts J. Appl. Microbiol. 86, 985-990.

12. Heisig $P$ (2001) Inhibitors of bacterial topoisomerases: mechanisms of action and resistance and clinical aspects. Planta Med. 67, 3-12.

13. Hostettmann K, Pettei MJ, Kubo I and Nakanishi K (1977) Direct obtaining of pure compounds from crude plant extracts by preparative liquid chromatography Lloydia. He/v Chim Acta. 60, 670-672.

14. Ikram M and Innamual H (1980a) Screening of medicinal plants for antimicrobial activity: part 1. Fitoterpia. 51, 231.

15. Ikram $M$ and Innamual $H$ (1980b) Screening of medicinal plants for antimicrobial activity part 2. FH S1:281.

16. Kirtikar KR and Basu BD (1971) Indian Medicinal Plants, Vol.3, $2^{\text {nd }}$ edn. Beshen Singh \& Mahandra Pal Singh, DehraDun, pp: 2327-2328.

17. Lorke D (1983) A new approach to practical acute toxicity testing. Arch. Toxicol. 54, 275-287.

18. Mandal SC, Mukherjee PK, Seha K, Pal M and Saha BP (1997) Antidiarrhoeal evaluation of Ficus racemosa Linn. leaf extract. Natural Products Science. 3, 2,100-103.

19. Mc Farland J (1987) Standardization of bacterial Culture for disc diffision assay. J. Am. Medical Assn. 49, 1176-1178.

20. Morebise O, Fafunso MA, Makinde JM, Olajide OA and Awe EO (2002) Antiinflammatory property of the leaves of Gongronema latifolium. Phytother. Res. 16, S75-77.

21. Aiyelagabe.O.O. (2000) Antibacterial activity of Jatropha multifida roots. Fitoterapia. 72, 544-546.

22. Mounissamy V, Darimane S and Gunasegaran R (2002) Antibacterial activity of Gosssypetin, isolated from Hibiscus saddriffa the antiseptic. The Antiseptic. 99, 81-82.

Research article

Clndian Society for Education and Environment (iSee)

"antidiarrhoeal herb" http://www.indjst.org
Vol.2 No 3 (Mar. 2009)

ISSN: 0974- 6846

23. Morebise $O$, Fafunso MA, Makinde JM, Olajide $O A$ and Awe EO (2002) Antiinflammatory property of the leaves of Gongronema latifolium. Phytother Res. 16, S75-77.

24. Murray JL, Zukiwski AA, Mujoo K and Rosenblum MG (1990) Recombinant alpha-interferon enhances tumor targeting of an antimelanoma monoclonal antibody in vivo. J. Biol. Response Mod. 9, 556-563.

25. Nostro A, Germanò MP, D'angelo $V$, Marino $A$ and Cannatelli MA (2000) Extraction methods and bioautography for evaluation of medicinal plant antimicrobial activity. Lett. Appl. Microbiol. 30, 379-384.

26. Odebiyi OO and Sofowora EA (1978) Phytochemical screening of Nigerian medicinal plants II. Lloydia. 41(3): 234-246.

27. Rath HC, Wilson KH and Sartor RB (1999) Differential induction of colitis and gastritis in HLA-B27 transgenic rats selectively colonized with Bacteroides vulgatus or Escherichia coli. Infect. Immun. 67, 2969-2974.

28. Rehan Ahmad, Swayam Prakash Srivastava, Rakesh Maurya, Rajendran SM, Arya KR and Arvind K. Srivastava (2008) Mild antihyperglycaemic activity in Eclipta alba, Berberis aristata, Betula utilis, Cedrus deodara, Myristica fragrans and Terminalia chebula. Indian J. Sci.Technol. 1 (5), 1-6. Domain site: http://www.indjst.org

29. Sahoo PK, Pillai BR, Mohanty J, Kumari J, Mohanty S and Mishra BK (2007) In vivo humoral and cellular reactions, and fate of injected bacteria Aeromonas hydrophila in freshwater prawn Macrobrachium rosenbergii. Fish Shellfish Immunol. 23, 327-340.

30. Sanders KM (1984) Role of prostaglandins in regulating gastric motility. Am. J. Physiol. 247, G117-126.

31. Tejani A, Pomrantz A, Khawar R and Fusi M (1986) Community acquired infections in children on maintenance cyclosporine therapy. Int. J. Pediatr. Nephrol. 7, 141-144.

32. Trease GE and Evans IC (1983) pharmacognasy $\left(12^{\text {th }}\right.$ edn) Bailliere Tindall London. pp:21-22.

33. Tripathi G (1994) Molecular weight of cytoplasmic malate dehydrogenase, mitochondrial malate dehydrogenase and lactate dehydrogenase of a freshwater catfish. Biomed. Environ. Sci. 7, 122-129.

34. Wink DA, Vodovotz Y, Grisham MB, DeGraff W, Cook JC, Pacelli R, Krishna M and Mitchell JB (1999) Antioxidant effects of nitric oxide. Methods Enzymol. 301, 413-424.

35. Woldemichael GM, Singh MP, Maiesew $M$ and Timmermann BN (2003) Constituents of antibacterial extract of Caesalpinia paraguariensis Burk.2. Nature Forseh. 58c, 70-75.

36. Yu LL, Liao JF and Chen CF (2000) Anti-diarrheal effect of water extract of Evodiae fructus in mice. $J$. Ethnopharmacol. 73, 39-45.

37. Zavala I, Barrera E and Nava A (1988) Ceftriaxone in the treatment of bacterial meningitis in adults. Chemotherapy. 34, 47-52. 